\title{
Editorial
}

Intervirology

\section{Controversy on Virus Designation: Alkhumra Sive Alkhurma Hemorrhagic Fever Flavivirus}

\author{
Uwe Gerd Liebert \\ Institut für Virologie, Universität Leipzig, Leipzig, Germany
}

Intervirology has decided to publish the ensuing letter by Madani et al. [1] and a response by Alzahrani et al. [2] concerning a prior publication [3]. As the letter by Madani et al. was obviously not accepted by EID, Intervirology feels that it is fair and appropriate to provide the authors the opportunity to discuss what they see as substantial errors in the work of Alzahrani et al. [3].

Taxonomy is apparently a matter that raises emotions. Disagreements between researchers on designation of a new virus have occurred in the past, one only has to remember the issue on HTLV-III versus LAV between renowned groups of researches that was eventually cleared. The virus is now named and unanimously accepted as HIV. Another example is the Sin Nombre hantavirus, which was originally named Four Corners virus and temporarily renamed Muerto Canyon virus.

There are no clear rules for the naming of new viruses. For arboviruses it is common use to name the virus according to geographical location, disease or vector (Kyasanur Forest disease virus, West-Nile virus, sandfly virus, tick-borne encephalitis virus, yellow fever virus, Japanese encephalitis virus). In the case of Alkhumra sive Alkhurma virus, the controversy has been ongoing for a while [4]. It should be remembered that not the name of a distinct virus species is disagreed on, but a mere genotype of Kyasanur Forest disease virus with about $89 \%$ identity to the prototype strain. Alzahrani et al. [2] quote the paper by Zaki [5]. From this paper, however, it is not possible to obtain information on where the index patient came from. While both names can probably be justified, it should be the discoverer who has the right to name a virus. The debate should come to an end once the ICTV has made its statement.

Another issue is that apparently errors have occurred in a prior publication [3]. Madani et al. question the conclusion of Alzahrani et al. ticks being the vector. While the figures provided in the two publications are clearly not congruent, the medical history put together retrospectively may or may not be entirely correct. Anyway, a conclusion from the mere number of cases as to the vector of the virus is probably not possible. There is an ongoing discussion on the transmission of Alkhumra sive Alkhurma virus. As it is a member of the TBE group of flaviviruses, it appears conceivable that it may be preferentially transmitted by ticks. In this line is the isolation of Alkhumra sive Alkhurma virus from ticks [6]. However, the epidemiological patterns put forward suggest a possible role of mosquitoes as vectors [7]. This issue should be solved by vector transmission studies in vitro and by isolation of the virus in nature. Therefore, either statement is at present speculative.

\section{KARGER}

Fax +4161306 1234

E-Mail karger@karger.ch

www.karger.com
(C) 2012 S. Karger AG, Basel

0300-5526/12/0554-0257\$38.00/0

Accessible online at:

www.karger.com/int
Prof. Dr. Uwe G. Liebert

Johannisallee 30

DE-04103 Leipzig (Germany)

Tel. +493419714300

E-Mail liebert@medizin.uni-leipzig.de 
A further issue is the inclusion of patients in the casecontrol study [3] on the basis of presence of IgG antibodies as a serological marker (parameter) for recent Alkhumra sive Alkhurma virus infection. As there are currently no data available on the persistence of IgM or IgG antibodies against this virus, the only readily available comparative data are from TBE virus. Here it was shown that IgM antibodies disappear after 40-60 days and IgG persists for years. It therefore appears correct to question the inclusion of these patients into the case group. Anyhow, the assumption is made solely on the basis of the data of related viruses.

\section{References}

1 Madani TA, Azhar EI, Abuelzein EME, Kao M, Al-Bar HMS, Niedrig M, Ksiazek TG: Alkhumra, not Alkhurma, is the correct name of the new haemorrhagic fever flavivirus identified in Saudi Arabia. Intervirology 2012;55:this issue.

2 Alzahrani AG, Al Shaiban HM, Al Mazroa MA, Al-Hayani O, MacNeil A, Rollin PE, Memish ZA: Alkhurma virus, subtype of Kyasanur Forest Disease virus, was described for the first time in Saudi Arabia. Intervirology 2012;55:this issue.
-3 Alzahrani AG, Al Shaiban HM, Al Mazroa MA, Al-Hayani O, MacNeil A, Rollin PE, Memish ZA: Alkhurma hemorrhagic fever in humans, Najran, Saudi Arabia. Emerg Infect Dis 2010;16:1882-1888.

-4 Charrel RN, Zaki AM, Fagbo S, de Lamballerie X: Alkhurma hemorrhagic fever virus is an emerging tick-borne flavivirus. J Infect 2006;52:463-464.

5 Zaki AM: Isolation of a flavivirus related to the tick-borne encephalitis complex from human cases in Saudi Arabia. Trans R Soc Trop Med Hyg 1997;91:179-181.
6 Mahdi M, Erickson BR, Corner AJ, Nichol ST, Rollin PE, Al Mazroa MA, et al: Kyasanur Forest Disease virus Alkhurma subtype in ticks, Najran Province, Saudi Arabia (letter). Emerg Infect Dis 2011;17:945-947.

7 Madani TA, Azhar EI, Abuelzein EME, Kao M, Al-Bar HMS, Abu-Araki H, Niedrig M, Ksiazek TG: Alkhumra (Alkhurma) virus outbreak in Najran, Saudi Arabia: epidemiological, clinical, and laboratory characteristics. J Infect 2011;62:67-76. 